DOI

\title{
МОРФОМЕТРИЧНА ОЦІНКА ОСОБЛИВОСТЕЙ РЕМОДЕЛЮВАННЯ КАМЕР ЛЕГЕНЕВОГО СЕРЦЯ З РІЗНИМИ ТИПАМИ КРОВОПОСТАЧАННЯ
}

\author{
ОМ. С. Гнатюк, О. Б. Слабий \\ ДВНЗ «Тернопільський державний медичний університет імені І. Я. Горбачевського МОз України»
}

\begin{abstract}
РЕЗЮМЕ. Морфометричними методами вивчені особливості ремоделювання камер серця з різними типами кровопостачання в умовах пострезекційної артеріальної легеневої гіпертензії. Встановлено, що легенева гіпертензія призводить до розвитку легеневого серця та вираженої структурної перебудови камер серця, яка характеризується незбалансованим, диспропорційним збільшенням їх маси та розширенням з переважаючою гіпертрофією і дилатацією правого шлуночка. Встановлена структурна перебудова камер серця залежить від типу кровопостачання серцевого м'яза, найвираженішою вона виявилася у легеневому серці з правовінцевим типом кровопостачання.
\end{abstract}

КЛЮчОВІ СЛОВА: ремоделювання, камери серця, легенева гіпертензія.

Вступ. В останні роки спостерігається ріст хронічних обструктивних захворювань легень, хронічних форм туберкульозу та професійних захворювань легень, при яких основною причиною інвалідності та смертності хворих $\epsilon$ хронічне легеневе серце [1, 2]. Патогенез хронічного легеневого серця складний та багатогранний, що суттєво ускладнює сучасну діагностику легеневої артеріальної гіпертензії та легеневого серця [2, 3]. Ріст судинного опору в малому колі кровообігу при різних хронічних ураженнях легень призводить до активації скоротливих резервів правого шлуночка з розвитком синдрому гіпердинамії та гіперфункції міокарда, в результаті яких розвива$\epsilon$ ться гіпертрофія правого шлуночка з наступною дилатацією на етапі декомпенсації хронічного легеневого серця [2]. На сьогодні недостатньо вивчені процеси, що детермінують зміни органного, тканинного та клітинного гомеостазів, ступінь порушення яких визначає компенсацію, субкомпенсацію та декомпенсацію легеневого серця [4-6]. Суперечливими, неоднозначними та недостатньо вивченими залишаються твердження щодо закономірностей ремоделювання камер серця при артеріальній гіпертензії у малому колі кровообігу. Сьогодні морфологи все ширше використовують морфометричні методи дослідження, які дозволяють отримати кількісну характеристику різних фізіологічних та патологічних процесів і логічно їх інтерпретувати [7]. У сучасній медико-біологічній літературі мало досліджень, в яких представлена комплексна морфометрична характеристика всіх камер серця при артеріальній гіпертензії у малому колі кровообігу.

Мета роботи: морфометричне вивчення особливостей ремоделювання камер легеневого серця з різними типами кровопостачання.

Матеріал і методи дослідження. Масометричними та планіметричними методами дослі- джені камери серця (лівий, правий шлуночки, ліве і праве передсердя) 48 статевозрілих свинейсамців в'єтнамської породи, які були поділені на 6 груп. 1-а група нараховувала 12 неушкоджених сердець з правовінцевим типом кровопостачання, 2-а - 7 досліджуваних органів з лівовінцевим типом кровопостачання, 3-я - 6 сердець з рівномірним розподілом вінцевих артерій, 4-а - 10 сердець з пострезекційною артеріальною легеневою гіпертензією та легеневим серцем з правовінцевим типом кровопостачання, 5-а - 6 аналогічних сердець з лівовінцевим типом кровопостачання, 6-а - 7 спостережень з пострезекційною легеневою гіпертензією та легеневим серцем 3 рівномірним типом кровопостачання $[8,9]$. Легеневу артеріальну гіпертензію та легеневе серце моделювали за допомогою правосторонньої пульмонектомії [3]. Тварини перебували у звичайних умовах на стандартному раціоні віварію. Оперативні втручання виконували в умовах тіопенталнатрієвого наркозу з дотриманням правил асептики та антисептики. Евтаназію дослідних тварин здійснювали кровопусканням в умовах тіопенталового наркозу. Серце виймали з грудної клітки і розрізали за методом Г. Г. Автанділова [7] у модифікації І. К. Єсипової [10]. Макрометрично визначали чисту масу серцевого м'яза - ЧМС (маса серця без клапанів, субепікардіальної жирової клітковини; великих судин), абсолютну масу лівого (МЛШ) та правого шлуночків - МПШ (маса шлуночка з пропорційною його масі частиною міжшлуночкової перегородки), масу лівого (МЛП) та правого (МПП) передсердь, шлуночковий індекс ШІ (відношення МПШ до МЛШ), індекс Фултона $[7,10]$ - ІФ (відношення маси лівого шлуночка 3 міжшлуночковою перегородкою до маси правого), індекс передсердь - ІПр (відношення МЛП до МПП), серцевий індекс - СІ (відношення ЧМС до маси тіла), відсотки мас шлуночків та передсердь 
Огляди літератури, оригінальні дослідження, погляд на проблему

(\% лш, \% ПШ, \% лП, \% ПП), площі ендокардіальних поверхонь лівого і правого шлуночків та передсердь (ПСЛШ, ПСПШ, ПСЛП, ПСПП), планіметричні індекси шлуночків (ПІ - ПСЛШ / ПСПШ) та передсердь (ПІПР - ПСЛП / ПСПП). Отримані кількісні показники обробляли статистично. 06робка результатів виконана у відділі системних статистичних досліджень ДВНЗ «Тернопільський державний медичний університет імені І. Я. Горбачевського МОЗ України» в програмному пакеті STATISTIKA. Достовірність різниці між порівнюваними параметрами визначали за критеріями Стьюдента та Манна-Уітні [11].

Результати й обговорення. Отримані в результаті проведеного дослідження масометричні та планіметричні параметри камер серця статевозрілих свиней-самців в'єтнамської породи представлені у таблицях 1,2 . У результаті всесто- роннього аналізу наведених у таблиці 1 даних встановлено, що морфометричні параметри неушкодженихсердецьз різнимитипамикровопостачання у досліджуваних тварин відрізнялися між собою. При цьому виявлено, що масометричні та планіметричні параметри частин серцевого м'яза статевозрілих свиней-самців в'єтнамської породи залежать від типів його кровопостачання. Маса лівого шлуночка та площа його ендокардіальної поверхні домінували у серцях з переважаючим лівовінцевим типом кровопостачання. Аналогічні кардіопараметри лівого та правого передсердь переважали у серцях з рівномірним розподілом лівої та правої вінцевих артерій. Співвідношення між масами камер серця, а також між площами їх ендокардіальних поверхонь найбільш зміненими виявилися при переважаючому лівовінцевому варіанті кровопостачання серцевого м'яза.

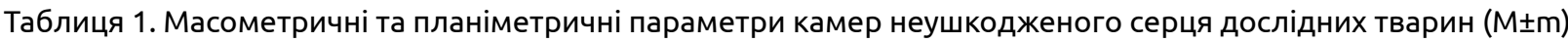

\begin{tabular}{|c|c|c|c|}
\hline \multirow{2}{*}{ Показник } & \multicolumn{3}{|c|}{ Група тварин } \\
\hline & $1-a$ & $2-a$ & 3-я \\
\hline 4MC, & $30,20 \pm 0,45$ & $32,46 \pm 0,51 *$ & $31,84 \pm 0,54^{*}$ \\
\hline МЛШ, г & $16,70 \pm 0,24$ & $19,50 \pm 0,33 * *$ & $18,20 \pm 0,30$ \\
\hline МПШ, г & $8,90 \pm 0,12$ & $8,40 \pm 0,15^{*}$ & $8,53 \pm 0,15$ \\
\hline МлП, г & $2,26 \pm 0,03$ & $2,32 \pm 0,04$ & $2,53 \pm 0,05^{*}$ \\
\hline МПП, г & $2,34 \pm 0,03$ & $2,24 \pm 0,03 *$ & $2,58 \pm 0,04^{* *}$ \\
\hline Шا & $0,532 \pm 0,007$ & $0,430 \pm 0,006 * * *$ & $0,468 \pm 0,008 * * *$ \\
\hline $\mathrm{Cl}$ & $0,00490 \pm 0,00012$ & $0,00510 \pm 0,00009$ & $0,00500 \pm 0,00009$ \\
\hline $1 \Phi$ & $2,62 \pm 0,04$ & $3,10 \pm 0,06 * *$ & $2,85 \pm 0,05^{*}$ \\
\hline IПр & $0,966 \pm 0,012$ & $1,030 \pm 0,018^{*}$ & $0,980 \pm 0,018$ \\
\hline \% лш & $55,3 \pm 0,8$ & $60,1 \pm 1,2^{*}$ & $57,20 \pm 1,02$ \\
\hline$\%$ ПШ & $29,47 \pm 0,42$ & $25,9 \pm 0,5^{* *}$ & $26,80 \pm 0,48^{* *}$ \\
\hline \% лП & $7,48 \pm 0,06$ & $7,15 \pm 0,14^{*}$ & $7,90 \pm 0,12 *$ \\
\hline$\%$ ПП & $7,75 \pm 0,09$ & $6,85 \pm 0,12 * *$ & $8,10 \pm 0,12 *$ \\
\hline ПСЛШ, $\mathrm{cm}^{2}$ & $17,20 \pm 0,24$ & $18,30 \pm 0,36^{*}$ & $18,40 \pm 0,33 * *$ \\
\hline ПСПШ, $\mathrm{CM}^{2}$ & $19,60 \pm 0,27$ & $19,70 \pm 0,42$ & $20,30 \pm 0,39$ \\
\hline$\Pi \mathrm{I}$ & $0,880 \pm 0,015$ & $0,930 \pm 0,018^{*}$ & $0,906 \pm 0,015$ \\
\hline ПСЛП, $\mathrm{CM}^{2}$ & $10,10 \pm 0,15$ & $10,50 \pm 0,21$ & $10,80 \pm 0,18^{* *}$ \\
\hline ПСПП, См² & $11,80 \pm 0,18$ & $12,40 \pm 0,24^{*}$ & $12,70 \pm 0,21$ * \\
\hline ПІПр & $0,856 \pm 0,012$ & $0,847 \pm 0,018$ & $0,850 \pm 0,015$ \\
\hline
\end{tabular}

Примітка. Зірочкою позначені величини, що статистично достовірно відрізняються від аналогічних 1-ї групи $(*-p<0,05 ;$ ** $p<0,01 ; * * *-p<0,001)$.

Відомо, що правостороння пульмонектомія, при якій видаляється більше половини судинного русла легень, призводить до артеріальної гіпертензії у малому колі кровообігу, гіперфункції та гіпертрофії правого шлуночка серця, тобто розвитку легеневого серця [3]. Отримані морфометричні параметри камер серця з різними типами кровопостачання свідчать, що через місяць після правосторонньої пульмонектомії (табл. 2) виражено зростають масометричні та планіметричні параметри шлуночків і передсердь. При цьому домінує збільшення маси та розширення правого шлуночка серця, що підтверджує наявність легеневого серця. Зростання маси та розширення інших камер серця пояснюється тим, що шлуночки та передсердя між собою анатомічно та функціонально пов'язані і при гіперфункції однієї камери гіперфункціонують та гіпертрофуються також інші частини серцевого м'яза $[6,12]$. Водночас отримані морфометричні параметри вказують, що при легеневій гіпертензії ступінь ремоделювання камер серця з різними варіантами кровопостачання 
Огляди літератури, оригінальні дослідження, погляд на проблему неоднаковий. Наведене адекватно демонструють відносні масометричні (Шا, ІФ, ІПр) і планіметричні (ПІ, ПІПр) параметри. Встановлено, що найбільшим Ш $(0,703 \pm 0,006)$ виявився у гіпертрофованих серцях з правовінцевим типом кровопостачання, дещо меншим $(0,601 \pm 0,003)$ - у 5-й групі (серця з рівномірним розподілом вінцевих артерій) і найменшим

$(0,583 \pm 0,004)$ - у спостереженнях з лівовінцевим типом кровопостачання. Наведене свідчить, що при структурній перебудові гіперфункціонуючого гіпертрофованого міокарда після пульмонектомії у серцях з правовінцевим типом кровопостачання маса правого шлуночка була найбільшою, що підтверджувалося також змінами ІФ, та \% ПШ.

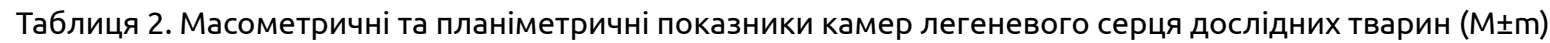

\begin{tabular}{|c|c|c|c|}
\hline \multirow{2}{*}{ Показник } & \multicolumn{3}{|c|}{ Група тварин } \\
\hline & 4-a & $5-a$ & 6-a \\
\hline ЧMC, $г$ & $36,70 \pm 0,42 * * *$ & $40,02 \pm 0,45^{* * *}$ & $37,64 \pm 0,42 * * *$ \\
\hline МЛШ, г & $18,10 \pm 0,21 * *$ & $21,60 \pm 0,24^{* *}$ & $19,80 \pm 0,21 * * *$ \\
\hline МПШ, г & $13,20 \pm 0,15^{* * *}$ & $12,90 \pm 0,12^{* * *}$ & $11,90 \pm 0,12^{* * *}$ \\
\hline МЛП, г & $2,50 \pm 0,03 * *$ & $2,60 \pm 0,04 * *$ & $2,74 \pm 0,03 * * *$ \\
\hline МПП, г & $2,90 \pm 0,03 * * *$ & $2,92 \pm 0,03 * * *$ & $3,20 \pm 0,04 * * *$ \\
\hline 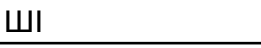 & $0,730 \pm 0,006 * * *$ & $0,583 \pm 0,004^{* * *}$ & $0,601 \pm 0,003$ \\
\hline $\mathrm{Cl}$ & $0,00550 \pm 0,00006 * *$ & $0,00570 \pm 0,00006 * *$ & $0,00560 \pm 0,00005^{* *}$ \\
\hline $1 \Phi$ & $2,10 \pm 0,03 * * *$ & $2,05 \pm 0,03 * * *$ & $2,07 \pm 0,03 * * *$ \\
\hline $\mathrm{I \Pi p}$ & $0,862 \pm 0,009 * * *$ & $0,890 \pm 0,006^{* * *}$ & $0,856 \pm 0,005^{* *}$ \\
\hline \% лШ & $49,30 \pm 0,60 * *$ & $53,90 \pm 0,54 * *$ & $52,6 \pm 0,45^{*}$ \\
\hline \% ПШ & $35,96 \pm 0,42 * * *$ & $32,20 \pm 0,39 * * *$ & $31,60 \pm 0,33 * * *$ \\
\hline \% лП & $6,82 \pm 0,06 * * *$ & $6,55 \pm 0,04^{*}$ & $7,30 \pm 0,03 * *$ \\
\hline$\%$ ПП & $7,92 \pm 0,06$ & $7,35 \pm 0,06 * *$ & $8,50 \pm 0,04 *$ \\
\hline ПСЛШ, $\mathrm{CM}^{2}$ & $20,80 \pm 0,24 * * *$ & $21,10 \pm 0,25^{* * *}$ & $21,30 \pm 0,24 * * *$ \\
\hline ПСПШ, $\mathrm{CM}^{2}$ & $30,40 \pm 0,21 * * *$ & $29,20 \pm 0,24^{* * *}$ & $28,40 \pm 0,27 * * *$ \\
\hline ПI & $0,684 \pm 0,012 * * *$ & $0,722 \pm 0,009 *$ & $0,750 \pm 0,008 * * *$ \\
\hline ПСЛП, $\mathrm{CM}^{2}$ & $11,90 \pm 0,12 * * *$ & $12,10 \pm 0,12 * * *$ & $12,15 \pm 0,09 * * *$ \\
\hline ПСПП, См² & $17,10 \pm 0,15^{* * *}$ & $16,90 \pm 0,12 * * *$ & $15,80 \pm 0,15^{* * *}$ \\
\hline ПІПр & $0,696 \pm 0,006 * * *$ & $0,715 \pm 0,005^{* * *}$ & $0,768 \pm 0,006^{* *}$ \\
\hline
\end{tabular}

Примітка: * - p<0,05; ** - p<0,01; *** - p<0,001 порівняно з аналогічними контрольними величинами.

На мікропрепаратах виділених стінок шлуночків серця та передсердь спостерігалася гіпертрофія м'ясистих перекладок (трабекулярних м'язів) та соскоподібних м'язів. Найбільш виражена гіпертрофія вказаних структур відмічалася у правому шлуночку з домінуванням правої вінцевої артерії (рис. 1).

Неоднаково у змодельованих умовах експерименту змінювалися також просторові параметри камер серця. Сказане адекватно демонстрували такі відносні планіметричні показники як ПІ та ПІПр. При цьому планіметричний індекс через місяць після правосторонньої пульмонектомії найменшим виявився у серцях з правовінцевим типом кровопостачання $(0,684 \pm 0,012)$, що вказувало на виражену дилатацію правого шлуночка, порівняно з лівим. Найбільша величина ПІ $(0,750 \pm 0,008)$ встановлена у 6-й групі спостережень (серця з рівномірним розподілом вінцевих артерій), де порушення відношень між планіметричними параметрами камер лівого та правого шлуночків було найменш вираженим.

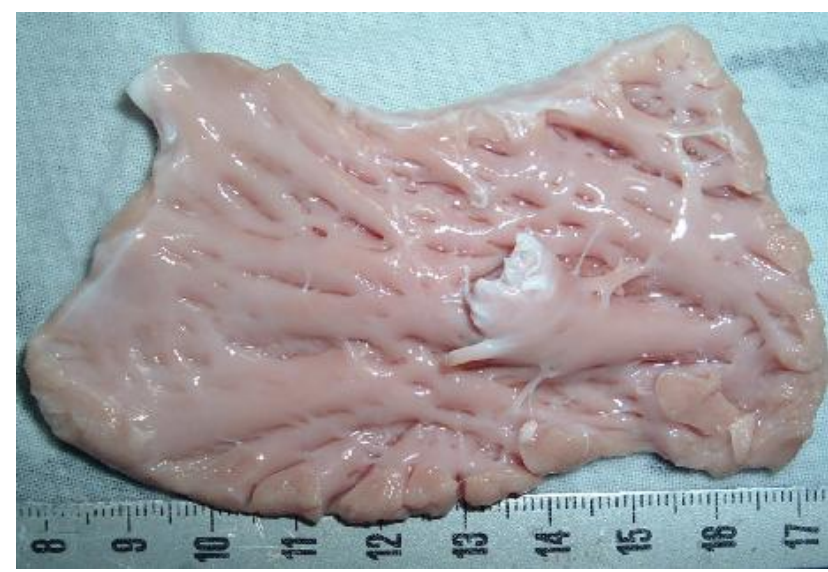

Рис. 1. Стінка дилатованого правого шлуночка легеневого серця з правовінцевим типом кровопостачання. Гіпертрофія м'ясистих перекладок та соскоподібного м'яза. Макропрепарат.

Аналогічні зміни спостерігалися при аналізі ПІПр, який у легеневому серці з правовінцевим типом кровопостачання виявився найменшим $(0,696 \pm 0,006)$, тобто ступінь розширення правого 
Огляди літератури, оригінальні дослідження, погляд на проблему

передсердя у даних спостереженнях домінував, порівняно з лівим. Виявлене свідчило, що вираженість дилатації правого передсердя була більшоюу 4-й групі спостережень. Встановлено також, що найбільшим ПІПр $(0,768 \pm 0,006)$ був у серцях 3 рівномірним розподілом вінцевих артерій, тобто порушення співвідношень між планіметричними параметрами лівого та правого передсердь у 6-й групі спостережень виявилося найменш вираженим. Необхідно зазначити, що, за твердженнями деяких дослідників, істотні порушення відношень між масами та просторовими характеристиками камер легеневого серця, які встановлені у наших спостереженнях, можуть призводити до дисфункції гіпертрофованого серцевого м'яза, тобто його декомпенсації $[5,6]$.

Висновки. Пострезекційна легенева артеріальна гіпертензія призводить до розвитку леге-

\section{ЛІТЕРАТУРА}

1. Амосова К. М. Клінічний перебіг та стан міокарда з хронічним легеневим серцем унаслідок хронічної обструктивної патології легень залежно від наявності легеневої гіпертензії / К. М. Амосова, Л. Ф. Конопльова, І. Д. Мазур // Серце і судини. - 2009. - № 2. - С. 48-52.

2. Норейко Б. В. Хроническое легочное сердце / Б. В. Норейко, С. Б. Норейко // Новости медицины и фармации. - 2011. - № 9 (364). - С. 14-17.

3. Гнатюк М. С. Морфометрична оцінка особливостей ремоделювання артерій шлуночків серця при пострезекційній артеріальній легеневій гіпертензії / М.С.Гнатюк, Л.В. Татарчук, О.Б.Слабий//Вісник проблем біології та медицини. - 2011. - Вип. 2, Т. 2. - С. 57-60.

4. Зиньковський М. Ф. Особенности морфологии и морфометрии миокарда при тетраде Фалло / М. Ф. Зиньковський, В. П. Захарова, Н. Ю. Загайнов // Серце і судини. - 2004. - № 1 (6). - С. 71-75.

5. Кирьякулов Г. С. Анатомия сложных врожденных пороков сердца / Г. С. Кирьякулов, В. А. ВасильєВ, Т. В. Бородий. - ДонецК : БАО, 2000. - 328 с.

6. Foppa M. Echocardiographically-based left ventricular mass. How should we define hypertrophy? / M. Foppa, B. Duncan, L. Rohde // Cardiovascular ultrasound. 2005. - Vol. 2. - P. 17-21. невого серця, вираженого ремоделювання камер серця, яке характеризується незбалансованим, диспропорційним збільшенням їх маси та розширенням з переважаючою гіпертрофією та дилатацією правого шлуночка. Встановлена структурна перебудова камер серця залежить від типу кровопостачання серцевого м'яза і найбільше вираженою $є$ у легеневому серці з правовінцевим типом кровопостачання.

Перспективи подальших досліджень. Детальне усестороннє дослідження особливостей ремоделювання камер легеневого серця з різними типами кровопостачання $\epsilon$ перспективним для врахування при діагностиці, корекції та профілактиці ускладнень пострезекційної легеневої артеріальної гіпертензії.

7. Автандилов Г. Г. Основы количественной патологической анатомии / Г. Г. Автандилов. - М. : Медицина, 2002. -240 с.

8. Коробкеев А. А. Морфометрическая характеристика типов ветвления артерий сердца человека / А. А. Коробкеев, В. В. Соколов // Морфология. - 2000. T. 117, № 1. - С. 34-36.

9. Кульчицкий К. И. Сравнительная анатомия и эволюция кровеносних сосудов сердца / К. И. Кульчицкий, О. Ю. Роменський. - К. : Здоров'я, 1985. - 176 с.

10. Есипова И. К. Метод срочной дифференциальной диагностики различных форм гипертензии малого круга кровообращения у секционного стола / И. К. Есипова, В. И. Алексеевич, Ю. С. Пурдяев // Суд. мед. експертиза. - 2003. - № 4. - С. 27-30.

11. Лапач С. Н. Статистические методы в медикобиологических исследованиях Excell / С. Н. Лапач, А. В. Губенко, П. Н. Бабич. - К. : Морион, 2001. -410 с.

12. Силкина Ю. В. Развитие проводящей системы В эмбриональном серце человека / Ю. В. Силкина // Вісник проблем біології та медицини. - 2011. - Вип. 2, T. 2. - C. 249-250.

\section{MORPHOMETRICAL EVALUATION OF THE PECULIARITIES OF REMODELING CHAMBERS OF COR PULMONALE WITH DIFFERENT TYPES OF BLOOD SUPPLY}

\section{M. S. Hnatiuk, O. B. Slabyi \\ I. Horbachevsky Ternopil State Medical University}

SUMMARY. The peculiarities of remodeling of chambers of the heart with different types of blood supply were studied by morphometric methods at postresection pulmonary arterial hypertension. It was established that the model pathology lead to cor pulmonale and pronounced structural reconstruction chambers of the heart which are characterized by disproportional and disbalance increasing of their mass and widen chambers of the heart with prevail hypertrophy and dilatation of the right ventricle. Structural changes of chambers of the heart depend on types of blood supply and prevail in cor pulmonale with prevalence right coronary artery.

KEY WORDS: remodeling, chambers of the heart, pulmonary hypertension. 